\title{
PROPRIEDADES EM TRAÇÃO DE COMPÓSITOS DE MATRIZ POLIÉSTER REFORÇADOS COM FIBRAS DE CÂNHAMO*
}

\author{
Anna Carolina Cerqueira Neves ${ }^{1}$ \\ Lázaro Araújo Rohen ${ }^{1}$ \\ Janaina da Silva Vieira ${ }^{1}$ \\ Carlos Maurício Fontes Vieira ${ }^{2}$ \\ Frederico Muylaert Margem ${ }^{3}$ \\ Sergio Neves Monteiro ${ }^{4}$ \\ Dhyemila de Paula Mantovani ${ }^{5}$
}

\begin{abstract}
Resumo
Muito se tem estudado sobre materiais alternativos, como os compósitos de matriz polimérica reforçados por fibras lignocelulósicas. Isso se justifica pelo fato das fibras naturais terem vantagens no que tange ao meio ambiente, bem como relativo baixo custo. Além disso, a fibra natural apresenta características de interface com a matriz polimérica que favorecem as propriedades mecânicas pela estrutura do compósito. Esse presente trabalho objetiva analisar as propriedades de tração de compósitos de matriz de poliéster reforçados com 10,20 e 30\% em fração volumétrica de fibras de cânhamo, que foram preparados alinhando as fibras em moldes e deixando-os curar por 24 horas em temperatura ambiente. Os corpos de prova foram testados numa máquina de ensaios Instron e os resultados mostraram um aumento na tensão máxima de ruptura com o aumento da porcentagem de fibra incorporada.
\end{abstract}

Palavras-chave: Fibra de cânhamo; Matriz poliéster; Propriedades de tração.

\section{TENSILE PROPERTIES OF POLYESTER MATRIX COMPOSITES REINFORCED WITH HEMP FIBERS}

\begin{abstract}
Much has been studied about alternative materials, such as polymeric matrices composites reinforced with lignocellulosic fiber. It's justified by the fact that natural fibers has environmental advantages and relatively low cost. Besides that, the natural fiber presents interfacial characteristics with polymeric matrices that favor the mechanical properties by the composite structure. This present work aims to analyses the tensile properties of a polyester matrix composite reinforced with 10, 20 and $30 \%$ in volume fraction of hemp fiber incorporation, which were prepared by laying down the fibers unto the plates along the entire length and cured in 24 hours in room temperature. The samples were tested in an Instron Machine and the results showed the increase in the tensile strength with the increase of fiber amount incorporation.
\end{abstract}

Keywords: Hemp fiber; Polyester matrix composite; Tensile properties.

1 Graduando(a) em Engenharia Metalúrgica e de Materiais, bolsista de iniciação científica, LAMAV, UENF, Campos dos Goytacazes, Rio de Janeiro - Brasil.

2 Doutor em Engenharia e Ciência dos Materiais pela Universidade Estadual do Norte Fluminense Darcy Ribeiro. LAMAV, UENF, Campos dos Goytacazes, Rio de Janeiro - Brasil.

3 Pós doutorando em Ciência e Engenharia de Materiais, Pós-doutorado, LAMAV, UENF, Campos dos Goytacazes, Rio de Janeiro - Brasil.

4 Professor PhD, IME, Rio de Janeiro, Rio de Janeiro - Brasil

5 Mestranda em Engenharia e Ciência dos Materiais, LAMAV, UENF, Campos dos Goytacazes, Rio de Janeiro - Brasil. 


\section{INTRODUCTION}

In recent years, there has been an increase application of natural fibers as reinforcement of polymeric matrix composites in several industrial sectors, with special participation in automobile components ${ }^{(1-3)}$. The advantage of natural fibers, especially those extracted from plants, over the glass fiber are presently a great motivation for the increasing use of "green" composites in automobiles (4-6). Glass fiber is more expensive, heavier and abrasive to processing equipment.

Moreover, this synthetic fiber presents a health risk when inhaled and its production is associated with $\mathrm{CO}_{2}$ emissions. None of these shortcomings apply to lignocellulosic fibers that, in addition, are renewable, biodegradable and neutral with respect to greenhouse gases, the major responsible for global warming. Application of natural fiber composites is rapidly increasing in the automobile industry with annual growth rates above $20 \%$ ( 7 ).

Less known natural fibers like piassava ${ }^{(8)}$, ramie ${ }^{(9)}$, curaua ${ }^{(10)}$ and buriti ${ }^{(11)}$ sisal (12) and other are currently being investigated for their potential as composite reinforcement. Hemp is one the lignocellulosic fiber with least knowledge as far as mechanical properties are concerned. Characterizations of these composites are being carried out for different polymer matrices and mechanical tests ${ }^{(12-22)}$.

However, no tensile characterization was done so far for polymer composites reinforced with hemp fibers. Therefore, the objective of this work was to conduct the tensile tests of polyester matrix composites reinforced with hemp fibers.

\section{EXPERIMENTAL PROCEDURE}

The material used in this work was untreated hemp fiber extracted from the stem hemp plant supplied by Desigan Natural Fibers Company and polyester resin. Statistical analysis were performed on one hundred fibers randomly removed from the as-received the lot. Figure 1 shows the histogram for the distribution of hemp fiber diameters by considering 6 diameter intervals. From this distribution, presented elsewhere an average diameter of $0.065 \mathrm{~mm}$ was found for the as-received lot.

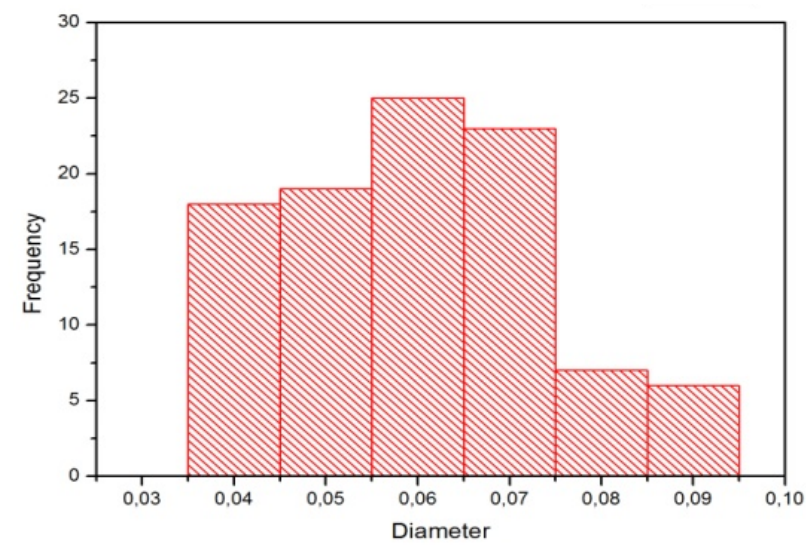

Figure 1.Distribution histogram for six diameter intervals.

For composite fabrication, the as-received hemp fibers were initially cleaned and then dried at $60^{\circ} \mathrm{C}$ for 24 hours. Tensile specimens were individually prepared by laying down continuous and aligned fibers in a rectangular "dog-bone" shaped silicone mold with $5.8 \times 4.5 \mathrm{~mm}$ of reduced gage dimensions. Fibers in amounts of up 
to $30 \%$ in volume were aligned along the $35 \mathrm{~mm}$ length of the specimens, corresponding to its tensile axis. The still fluid polyester resin, plus $0.5 \%$ of caralyst based on methyl ethyl ketone, was poured onto the fibers in the mold and allowed to cure for 24 hours and at room temperature. Some composite specimens were fabricated for each fiber composition. Each specimen was room temperature tested in a model 5582 Instron universal machine at a strain rate of $3 \times 10^{-3} \mathrm{~s}^{-1}$. The fracture surface of selected specimens was gold sputtered and then analyzed by scanning electron microscopy (SEM) in a model SSX-550 Shimadzu microscope operating at an accelerating voltage of $7-15 \mathrm{kV}$.

\section{RESULTS AND DISCUSSION}

Figure 2 exemplifies the typical load vs. extension curves for different composites. These curves were recorded directly from the Instron machine and revealed that the hemp fiber reinforced composites apparently present limited plastic deformation. Consequently, these composites, in principle, may be considered as brittle materials.
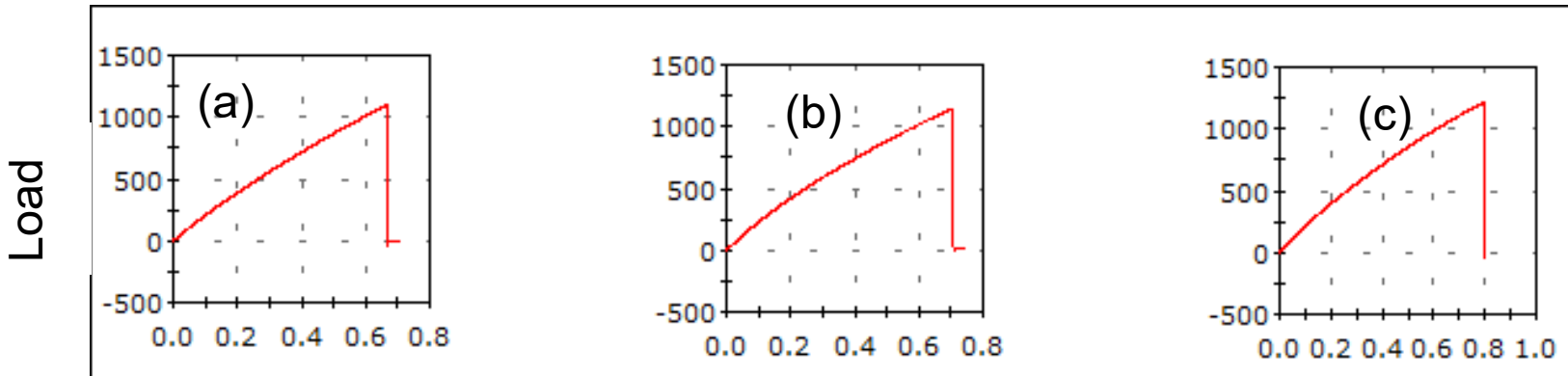

\section{Elongation}

Figure 2. Load vs. elongation curves for polyester composites reinforced with (a) $0 \%$, (b) $10 \%$ and (c) $30 \%$ of volume fraction of hemp fibers.

From the results of the load vs. elongation curves, Fig. 2, the ultimate stress (tensile strength), elastic modulus, and total strain were calculated. Table 1 shows the average values for these tensile properties for the different amounts of hemp fiber investigated.

Table 1. Tensile properties for the hemp fiber reinforced polyester composites.

\begin{tabular}{ccc}
\hline $\begin{array}{c}\text { Amount of Hemp } \\
\text { Fiber (Vol. \%) }\end{array}$ & $\begin{array}{c}\text { Tensile Strength } \\
\text { (Mpa) }\end{array}$ & $\begin{array}{c}\text { Elastic Modulus } \\
\text { (Gpa) }\end{array}$ \\
\hline $\mathbf{0}$ & $28.99 \pm 6.58$ & $0.83 \pm 0.23$ \\
$\mathbf{1 0}$ & $37.43 \pm 3.29$ & $1.88 \pm 0.16$ \\
$\mathbf{2 0}$ & $45.56 \pm 6.73$ & $1.70 \pm 0.05$ \\
$\mathbf{3 0}$ & $53.08 \pm 3.28$ & $1.75 \pm 0.13$ \\
\hline
\end{tabular}

Figure 3 plots the results of tensile strength and elastic modulus in Table 1 as a function of the volume fraction of hemp fibers. In this figure it should be noted that 
both the composite tensile strength and stiffness significantly increase with the hemp fiber incorporated into the polyester matrix.

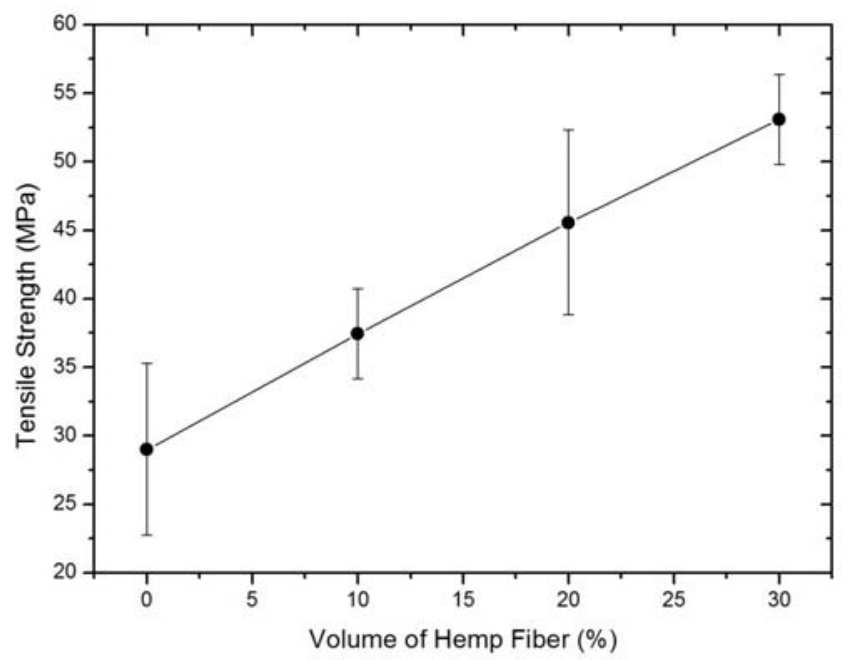

Figure 3 - Tensile strength variation with the amount of hemp fiber in the composite.

The elastic modulus variation in Fig 4 could also be adjusted to a linear relation and demonstrates a relevance increase in it values with the increase of fibers in the matrix. This can be attributed to the same mechanical proprieties analyzed for the tensile strength.

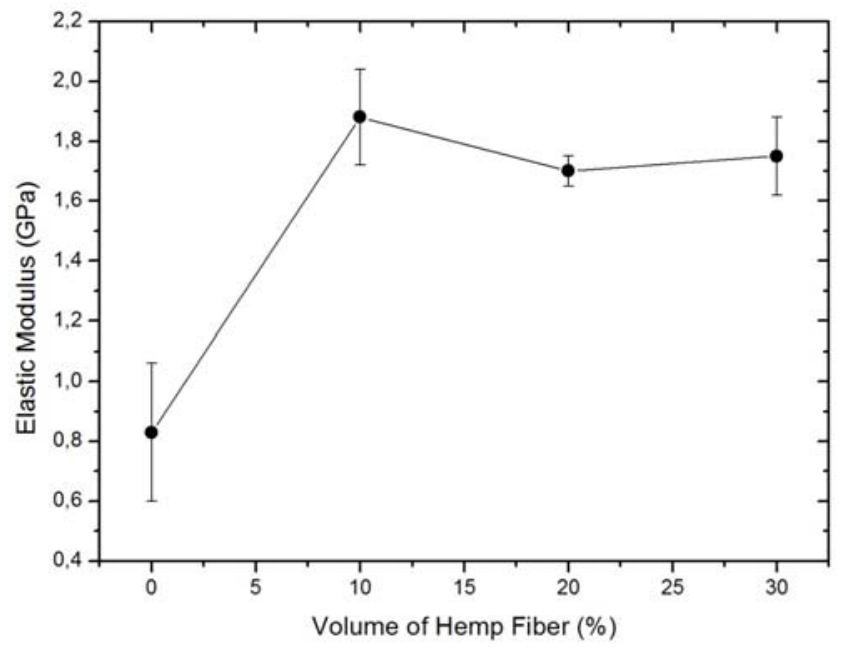

Figure 4. Variation of the elastic modulus with the volume fraction of hemp fiber reinforcing polyester composites.

\section{CONCLUSIONS}

The incorporation of continuous and aligned hemp fibers significantly increases the tensile strength and stiffness of polyester matrix composites.

An apparent linear increase occurs up to a volume fraction of hemp fiber of $30 \%$. This corresponds to a better performance than similar composite that were flexural tested.

\section{REFERENCES}

1 S. Hill, "Cars that grow on trees". New Scientists, 153(2067) (1997) 36-39.

2 G. Marsh, "Next step for automotive materials". Mater. Today, 6(4) (2003) 36-43 
3 R. Zah, R. Hischier, A.L. Leão, I. Brown, "Curaua fibers in automobile industry - A sustainability assessment”. J. Cleaner Production, 15, (2007) 1032-1040.

4 G. Marsh, "Next step for automotive materials". Mater. Today, 6(4) (2003) 36-43.

5 S. Hill, "Cars that grow on trees". New Scientists, 153(2067) (1997) 36-39.

6 R. Zah, R. Hischier, A.L. Leão and I. Brown, "Sisal fibers in automobile industry - A sustainability assessment". J. Cleaner Production, 15, (2007) 1032-1040.

7 R. Zah, R. Hischier, A.L. Leão and I. Brown, "Sisal fibers in automobile industry - A sustainability assessment". J. Cleaner Production, 15, (2007) 1032-1040

8 J.R.M. d'Almeida, R.C.M.P. Aquino and S. N. Monteiro, "Tensile Mechanical Properties, Morphological Aspects and Chemical Characterization of Piassava (Attalea funifera) Fibers". Composites. Part A, 37 (2006), 1473-1479.

9 C. Z. Paiva Jr., L.H. Carvalho, V.M. Fonseca, S.N. Monteiro, J.R.M. d'Almeida, "Analysis of the tensile strength of polyester/hybrid ramie-cotton fabric composites", Polymer Testing, 23(2) (2004) 131-135.

10 S.N. Monteiro, R.C.M.P. Aquino, F.P.D. Lopes, E.A. Carvalho and J.R.M. d'Almeida, "Mechanical Behavior and Structural Characteristics of Polymeric Composites Reinforced with Continuous and Aligned Curaua Fibers" (in Portuguese), Rev. Mater., 11(3) (2006) 197-203.

11 R.S. Santos, E.L.C. Silveira and C.M.L. Souza, "Study of the mechanical properties of thermoset polymeric matrix composites reinforced wit buriti fibers" (in Portuguese), Proceedings of the 30th Annual Meeting of the Brazilian Chemistry Society, (Aguas de Lindoia, Brazil, 2007) 1.

12 S.N. Monteiro, J.F. de Deus and J.R.M. d'Almeida, "Interfacial Strength of Sisal Fiber Reinforced Polyester Composites", Proceedings of SAM-CONAMET (Mar del Plata, Argentina, 2005) 1-6.

13 S.N. Monteiro, R.C.M.P. Aquino, F.P.D. Lopes, E.A. Carvalho and J.R.M. d'Almeida, "Mechanical behavior and structural characteristics of polymeric composites reinforced with continuous and aligned curaua fibers". Rev. Mater, 11(3) (2006) 197-203.

14 S.N. Monteiro, J.F. de Deus and J.R.M. d'Almeida, "Mechanical and structural characterization of curaua fibers", Proceedings of Characterization of Minerals, Metals \& Materials - TMS Conference, (San Antonio, USA, March, 2006) 1-8.

15 K.G. Satyanarayana, J.L. Guimarães, F. Wypych, "Studies on lignocellulosic fibers of Brazil. Part I: Source, production, morphology, properties and applications". Composites: Part A, 38, (2007) 1694-1709.

16 S.N. Monteiro, R.C.M.P. Aquino, and F.P.D. Lopes, "Performance of sisal fibers in pullout tests". J. Mater. Sci. 43 (2008) 489-493.

17 S.N. Monteiro, A.S. Ferreira and F.P.D. Lopes, "Rupture mechanisms in composites reinforced with sisal fibers", Proceedings of Characterization of Minerals, Metals \& Materials - TMS Conference, (New Orleans, USA, March, 2008) 1-8.

18 R.V. Silva, E.M.F. Aquino, L.P.S. Rodrigues and A.R.F. Barros, "Curaua/Glass Hybrid Composite: The Effect of Water Aging on the Mechanical Properties", J. Reinforced Plast. \& Comp., 28 (2009) 1857-1868.

19 S.N. Monteiro, A.S. Ferreira and F.P.D. Lopes, "A comparative study of sisal fiber reinforced epoxy matrix composites as building materials", Proceedings of the Global Symposium on Recycling, Waste Treatment and Clean Technology - REWAS2008, (Cancun, Mexico, October 2008) 1653-1658.

20 R.V. Silva and E.M.F. Aquino,"Curaua fiber: A new alternative to polymeric composites", J. Reinforced Plast. \& Comp., 27(1) (2008) 103-112.

21 S.N. Monteiro, A.S. Ferreira and F.P.D. Lopes, "Pullout tests of curaua fibers in epoxy matrix for evaluation of interfacial strength", Proceedings of Characterization of Minerals, Metals \& Materials - TMS Conference, (San Francisco, USA, March, 2009) 1-7.

22 S.N. Monteiro, A.S. Ferreira and F.P.D. Lopes, "Izod impact energy of polyester matrix composites reinforced with aligned curaua fibers", Proceedings of Characterization of Minerals, Metals \& Materials - TMS Conference, (San Francisco, USA, March, 2009) 1-8. 